\title{
ASSOCIATING TO CREATE UNIQUE TOURIST EXPERIENCES OF SMALL WINERIES IN CONTINENTAL CROATIA - OPPORTUNITIES AND CONSTRAINTS
}

\author{
Rikard Bakan \\ Dejan Tubić \\ Božidar Jaković
}

https://doi.org//10.20867/tosee.06.4

\begin{abstract}
Purpose - the purpose of this paper is to explore the possibilities of creating an integrated tourist product based on traditional wine production, wine culture and gastronomy, heritage and customs on the example of a small wine-growing area in Virovitica-Podravina County.

Methodology - the authors of this paper wanted to examine the views and attitudes of small winery owners considering possibilities of developing a wholesome oeno-gastro experience. Based on the studied literature connected with wine and gastrotourism and the experience economy, as well as based on a field research of the mentioned area, the authors have conducted a structured in-depth interview with the president of Pitomača vine growers' association and focus group with five winery owners to obtain information on their familiarity with scattered hotel models and the concept of unique tourism products based on the experience economy. Following the interview and data obtained through a focus group, a survey was conducted on a sample of fifteen respondents with the purpose of examining the attitudes of winery owners towards the opportunities and limitations for the development of this tourist product.

Findings - the data obtained through the survey indicate the fact that most of the respondents are not familiar with the concept of scattered hotels or the opportunities provided by the market with the development of modern, personalized tourist experiences. Even though the respondents see the potential for developing such tourist product in the examined area, they encounter many obstacles in their reflection, which limits their inclusion in the tourist offer.

Contribution - this paper can contribute to raising the awareness of local stakeholders for developing a unique offer by evaluating the existing, unused resources.

Keywords: wine tourism, gastro tourism, micro-clusters, scattered hotel, experience economy, rural environment.
\end{abstract}

\section{INTRODUCTION}

The growing popularity of wine tourism, defined as "visitations to vineyards, wineries, wine festivals, and wine shows for which grape wine tasting and/or experiencing the attributes of a grape wine region are the prime motivating factors for visitors" (Hall et al. 2000,3) in one of the first definitions, is increasing in parallel with the increase in the demand for rural tourism (Quadri-Filetti and Fiore 2012, 3). As can be deduced from the very definition of wine tourism, modern tourists expect much more than just tasting wine in a winery or a cellar - they expect a rounded single-tourist experience (Back et al. $2021,103)$. Judging by the preferences of most modern tourists, intangible, experiential elements that accompany the tasting and consumption of food and beverages, are those 
ToSEE - Tourism in Southern and Eastern Europe, Vol. 6, pp. 53-68, 2021.

R. Bakan, D. Tubić, B. Jaković: ASSOCIATING TO CREATE UNIQUE TOURIST EXPERIENCES ...

elements of the offer that contribute most to the authenticity and diversity of individual tourist destinations and catering facilities (Binkhorst and Den Deckker 2009, 313). Nowadays, gastronomy and oenology are one of the most important means of preserving the identity and familiarizing with the local culture, as well as an important distinguishing element for positioning in the tourism market (Hjalager and Richards $2002,8)$. Authenticity also stands as an important element of experience for modern oeno and gastro tourists (Jang et al. 2011, 665; Le et al. 2019, 257). Local food and drinks, as well as the authentic ambience in which they are produced and consumed attract more and more tourists. Socially and culturally aware tourists, like most tourists are today, appreciate the ethics and tradition in small farmers' production, the traceability of food from field to table, safety and hygiene of food, but even more the feeling of their tourist consumption contributing to the preservation of traditional agricultural production and rural areas. (Mirosa and Lawson 2012, 816; Kauppinen-Räisänen et al. 2013, 667; Björk and Kauppinen-Räisänen 2016, 295). It can therefore be concluded that agritourism farms, in this case those engaged in the production of grapes and wine together with other experiences related to the tradition of winemaking and the specifics of rural areas, can become the bearer of a unique gastronomy experience and lifestyle tourism. This mainly refers to those farms that deal with the traditional way of agricultural production, apply traditional recipes, preserve the traditional rural way of life and associate into an integral oeno and gastro tourism product. On the other hand, the vineyards in the area examined in this research are neither recognizing the potential of the region for the development of tourism nor expanding their core business with catering and tourism services. The reason for this lies in the fact that, as the respondents themselves stated, there is a lack of information about the various programs available to them, as well as a lack of their personal resources and bureaucratization of society in seeking incentives, but also in the fact that, as they emphasize, there is a low level of motivation and practice of associating between the stakeholders. Many successful examples in the world have shown that small wineries need to join and create microclusters in order to to succeed in the tourism market, whether this means joining into thematic routes, short supply chains or accommodation facilities such as scattered hotels (Villanueva and Moscovici 2016, 317). Therefore, the aim of this paper is to investigate whether the owners of small wineries in the vineyards of Pitomača see the potential for developing the tourist offer of wine tourism after the implementation of the program of building a tourist interpretation centre in the vineyards by associating their offer within scattered hotels as well as to investigate their viewpoints on the constraints that hinder their entrepreneurial initiative and the role that the local community should play in encouraging interest associations.

\section{WINE CULTURE - A BASIC RESOURCE FOR THE DEVELOPMENT OF ROUNDED TOURIST EXPERIENCES}

Wine and experiences related to wine tasting as well as the places where it is produced are key attractions of wine tourism. However, as emphasized by Hall et al. (2000, 6), the heart of wine tourism and wine experience is a combination of characteristics and preferences of wine tourists and products, i.e. the experience of wine tourism, while the experience of wine tourism itself is a combination of many elements from the destination environment (Hall et al. 2000, 7). Tourists are no longer willing to pay only for a basic service but are willing to pay extra for an experience of a rounded tourism product, in 
ToSEE - Tourism in Southern and Eastern Europe, Vol. 6, pp. 53-68, 2021.

R. Bakan, D. Tubić, B. Jaković: ASSOCIATING TO CREATE UNIQUE TOURIST EXPERIENCES ...

this case the product of wine tourism, Therefore, wine tourism service providers need to enrich their basic products with experiential elements in order to differentiate their products and achieve premium prices in addition to the necessary associating into a kind of integrated wine tourism association. The need to enhance products and services to experiential elements was first tackled by the authors Pine and Gilmore $(1999,30)$ and the phenomenon of experience economy and tourism was later studied by many other authors such as Mehmetoglu and Engen (2011, 242); Quadri-Filetti and Fiore (2012, 5); Quadri-Filetti and Fiore (2013, 49); Sundbo and Sorensen (2013, 429); Back at al. (2021, 105). Local producers, wineries and wine shops can become extremely competitive in the tourism market if they provide an authentic oeno and gastro tourism experience that allows the guest to fully blend with the environment and atmosphere, enjoy the experience of food and wine and intangible elements connected to it - such as storytelling and participation in the creation of their own experiences (Hawley 2017, 50; OECD 2012 21; Getz and Brown 2006, 149). By visiting such facilities, tourists not only enjoy an authentic oeno and gastro experience but also a new culture that greatly differs from the culture in places of their permanent residence (Fields 2003, 38). This arouses the tourists' interest in visiting other attractions in the area, their awareness of the authenticity of the destination as a place of a pleasant environment and meaningful stay, and thus the gastronomy products become the bearers of the recognizability of the entire tourist destination. From the perspective of today's tourist, as stated by the authors Aref et al. (2010, 82); and Frost et al. (2020, 2), the specifics and uniqueness of local communities are becoming one of the main reasons for tourist travel. Such destinations can count on long-term recognition in the tourism market if the development of the tourist offer in tourist destinations is based on key attractions of tangible heritage but even more on the intangible heritage as well as on consumption of quality products produced in the destination environment, which are recognizable in the market precisely because of local characteristics enriched with additional elements of tourist experience (Herrera 2012,8).

\section{CLUSTERING IN FUNCTION TO ACHIEVING COMPETITIVENESS AND RECOGNITION IN THE WINE TOURISM MARKET}

Interest grouping and associating are most frequently connected to the term of cluster. Many definitions of clusters can be found in the literature, but one of the most cited ones is that of Michael Porter, who defines clusters as "geographically oriented groups of related companies and institutions in a particular sector, linking togetherness and complementarity" (Porter 1990, 8). The advantages brought by clusters are the increase of the area of business activity of related entities and other stakeholders significant for the competitiveness. Other advantages of clustering are also the increased access to consumers, increased customer satisfaction and direct benefit primarily of producers of complementary products and companies in relation to skills, technologies and other tangible and intangible (Dragičević 2012, 62) heritage. The essence of market success in the era of global competition in tourism lies, among other things, in the cooperation of all tourism service providers among themselves as well as their cooperation with other complementary stakeholders in the destination. In this context, the success of wine and gastro tourism products within agritourism farms will depend primarily on the cooperation of all owners of vineyards and other stakeholders in the destination in order to establish standards of a tourist value chain and the delivery of unique oeno and gastro 
ToSEE - Tourism in Southern and Eastern Europe, Vol. 6, pp. 53-68, 2021.

R. Bakan, D. Tubić, B. Jaković: ASSOCIATING TO CREATE UNIQUE TOURIST EXPERIENCES ...

tourism experience based on authenticity, intangible and tangible heritage, and the way of life of the local community (Jennings and Nickerson 2006, 116; Herrera 2012, 6; Lee, et al. 2015, 134). Michael Porter $(1998,79)$ mentions the Cluster of the California wine industry as one of the successful examples of associating, emphasizing that the mentioned owes its market success to the association of numerous complementary producers and other stakeholders within the entire California wine tourism offer. The author Michael also writes about the forms of clusters and examples of interesting associations in tourism in the article "Tourism micro-clusters" (Michael 2003, 133) in which he states various possibilities of associating, primarily vertically and horizontally, but adds that the association can be extended to a diagonal approach that respects the best characteristics of both modes of association (Michael 2003, 137). It is this diagonal approach that the author points out as the most applicable in tourism because it brings together stakeholders who, although offering different tourism products and services separately, complement each other and offer a complete, unique tourism product in the market, thus raising their competitive advantage. So for example, a local cheese producer can market his product as part of a tourist experience within a tourist wine cluster, even though his main activity does not have any major contact points with tourism at first glance, nor is his family farm registered for tourist activities.

\subsection{Scattered hotels as an opportunity to associate small winemakers in the tourist market}

The first consideration of the concept of scattered hotels (Albergo Diffuso) appeared in the late 70 's of the $20^{\text {th }}$ century in the Italian region of Carniola at the beginning of the reconstruction of earthquake-stricken settlements in order to stop emigration from small communities. However, the concept came to life only in 1995 when the first hotel of this kind opened in Nuoro, Sardinia (Morena et al. 2017, 451). Albergo Diffuso, also known as a Scattered or Widespread hotel is "a sustainable and innovative form of hotel that originates in enhancing historical and cultural real estate heritage, characterized by original structures, places (rural areas or small urban centres) and persons involved (both residents and tourists) in the production and distribution process and with experiential authenticity" (Paniccia and Leoni 2019, 6). The elements by which scattered hotels differ from classic hotels are 1) unique management by a registered caterer; 2) accommodation facilities which are concentrated near the centre of a small town or in the area of a small village and which exude a tradition and architecture characteristic to the area; 3 ) existence of traditional production, agriculture and/or crafts; 4) local residents living and working in the mentioned area; 5) owners and managers of facilities are local residents; 6) accommodation facilities and other facilities that provide services to tourists are up to 200 meters apart; 7) the whole area exudes the authentic spirit of a small town or village; 8) services offered to guests specialize with regard to the basic activities of the population (wine, food, traditional crafts, art, etc.); 9) the concept of integrated quality management is applied (Cucari et al. 2019, 106). In Croatia, too, the concept of scattered hotels and Albergo Diffuzo is recognized as an opportunity to associate small businesses in tourism in order to be more competitive in the market, so amendments to the Ordinance on the categorization of hotels (NN 33/2014, Art. 2) introduce two additional types namely: diffuse hotel (Albergo Diffuso) and integral hotel (integrated, scattered or widespread hotel). With many similar characteristics to the original concept originated in Italy, the 
ToSEE - Tourism in Southern and Eastern Europe, Vol. 6, pp. 53-68, 2021.

R. Bakan, D. Tubić, B. Jaković: ASSOCIATING TO CREATE UNIQUE TOURIST EXPERIENCES ...

legislation in Croatia still makes a distinction between diffuse and integral hotels. For diffuse hotels it is stated that they must be 1) located in predominantly old, traditional, historical, rural-urban structures and buildings, decorated and equipped in the traditional way; 2) a functional unit in the area of one settlement consisting of three or more widespread and functionally connected buildings, integrated into the local environment and way of life; 3 ) accommodation units can be: rooms, hotel suites, family rooms, studio apartments and suites. Integral hotels, on the other hand, 1) do not necessarily have to be located in old, traditional buildings, but are formed by a functional unit in the area of one settlement with common facilities that are combined and previously categorized and/or classified facilities into three or more common buildings; 2) within the integral hotel, the registered caterer provides catering services in common facilities, his facilities and/or facilities of other owners with which the facility was associated; 3 ) all associated members should have previously obtained solutions for some of the following facilities: a) for the provision of catering services in the household (except in case of household camps); b) catering facilities for accommodation, with star-marked categories from the group "Camps and other types of catering facilities for accommodation"; c) from the groups Restaurants, Bars, Catering facilities and Facilities of simple services. The already mentioned authors Morena et al. $(2017,453)$ note the following factors as the key success factors of this type of combined tourism and hospitality offer of small rural areas:

- Accommodation in a rural area that appears attractive to tourists (countryside, seaside, mountains, castles, spas...)

- Recognizable elements of local culture, lifestyle, and work of the residents (home made products, local food and wine, events, folklore, traditional crafts...)

- Proximity of basic services for tourists (shops, infirmaries, banks...)

- Tourist awareness of the local population and the desire to share the experience of local life with tourists

- Service adeptness and thematization of tourist experience (food and wine experience, creative workshops, art experience...).

As can be seen from the above, the concept of scattered hotels in rural areas fits into the preferences of the so-called "third generation" of tourists who seek unique tourist experiences and full integration into the life of the local community during holidays leading to the growing popularity of niche tourism and similar forms of accommodation in the tourism market (Wu et al. 2017, 515; Cucari et al. 2019, 108).

\section{RESEARCH STARTING POINTS}

Prior to the empirical research, the authors sought to set the starting points through three research steps:

- Desk and field research

- Interview with the chairman of the association of winegrowers

- Focus group of winemakers of the subject area. 
ToSEE - Tourism in Southern and Eastern Europe, Vol. 6, pp. 53-68, 2021.

R. Bakan, D. Tubić, B. Jaković: ASSOCIATING TO CREATE UNIQUE TOURIST EXPERIENCES ...

First, a desk and field research were made for the mentioned area in order to determine tourism indicators for the observed area, analyse the characteristics of the destination in terms of tourist attraction base, plans for tourism development and the project of building a tourist interpretation centre in the vineyard area. For this purpose, the authors have analysed data on arrivals and realized overnight stays in the past five years (Tourist board of Pitomača, 2020) as shown in Table 1 from which it can be seen that the average number of tourist arrivals per year is 815 and 1783 overnight stays.

Table 1: Arrivals and overnight stays in the Municipality of Pitomača from 2016 to 2020

\begin{tabular}{lrrrrrr}
\hline & 2016. & 2017. & 2018. & 2019. & 2020. & average \\
\hline arrivals & 748 & 841 & 952 & 982 & 551 & 815 \\
overnight stays & 1500 & 1995 & 2717 & 1836 & 865 & 1783 \\
\hline
\end{tabular}

Source: processed by the authors according to the data from Tourist board of Pitomača Annual reports from 2017. to 2020 .

These indicators show that tourist trends are at a very modest level, which is, among other things, due to the small number of accommodation capacities and the lack of complete tourist facilities. On the other hand, the study of the Master Plan for Tourism Development in the Municipality of Pitomača until 2020 (The Official website of Pitomača Municipality 2015) indicated that the Municipality of Pitomača has a very rich tourist attraction base on which oeno and gastro tourism is emphasized as one of the key tourism products. The local self-government has undertaken a number of initiatives to create an environment that would encourage private entrepreneurs to invest in the development of the tourist offer. One of those projects is a project called EAGLE through which the Municipality of Pitomača, in cooperation with the partner city of Pecz in Hungary, seeks to develop two interconnected visitor interpretation centres with a strengthened, fully functioning Hungarian-Croatian stakeholder network; sustainably develop and promote natural and cultural attractions associated with the visitor centre in the vineyards and generate economic growth through stakeholders in the area of tourism. Precisely the realization of the mentioned project that plans the building of an excursion complex with a lookout, wine cellar and interpretation centre was the starting point for the next phase of the research, i.e. for the field research of vineyards conducted during March 2021 as well as an in-depth interview with the president of the association of winegrowers "Aršanj" from Pitomača. By means of this research, the authors sought to examine the following research points: characteristics of the vineyards; the extent to which the local winegrowers are familiar with the purpose, goals and dynamics of building a tourist information centre in the vineyards; the number of small winemakers in the area, their current market position and activities undertaken in terms of encouraging members to supplement their core business with tourism services. Upon conducting the research, a focus group was formed at the proposal of the President of the association, consisting of the five most active members of the association, registered grape and wine producers, with whom the authors further discussed the characteristics of their vineyards, their thoughts on the possibility of their inclusion in the tourist offer of wine tourism after the implementation of the project of the tourist interpretation centre and the possibility of integral association of small wine producers with the emphasis on 
ToSEE - Tourism in Southern and Eastern Europe, Vol. 6, pp. 53-68, 2021.

R. Bakan, D. Tubić, B. Jaković: ASSOCIATING TO CREATE UNIQUE TOURIST EXPERIENCES ...

the concept of a scattered hotel as a model for a joint participation in the wine tourism market. Based on this, the authors have defined the main starting points of the research:

- the observed area has comparative advantages for the development of wine tourism (195.88 hectares made of vineyards (Development Strategy of the Municipality of Pitomača until 2020, 2015; 86), 550 to 600 holiday homes ${ }^{1}$ with vineyards with all the necessary infrastructure, specific organoleptic properties of wine due to the sandy composition of the soil, traditional wine production based on recognizable elements of intangible heritage, good spatial organization of vineyards and good connections with major traffic routes)

- currently there are no registered wine cellars with accommodation capacities

- winegrowers are familiar with the opportunities that the market offers them by supplementing the offer of their own vineyards with the tourist offer

- significant interest in integral association in terms of creating a recognizable offer of wine and gastronomic tourism has been noticed

- the winemakers see the project of the tourist interpretation centre as an incentive for the development of wine tourism offer

- winegrowers expect the help of the local self-government in their entrepreneurial initiatives.

Based on primary and secondary research starting points, it seemed justified to conduct an empirical research to determine the awareness of small winery owners about the tourist attractiveness of the area after the construction of the interpretation centre and the potentials, opportunities and obstacles of their inclusion in the tourist offer through joining into a scattered hotel and developing a rounded oeno and gastro tourism experience.

\section{PRIMARY RESEARCH AND DATA ANALYSIS}

\subsection{Methodology}

The empirical research is based on the data and information from a preliminary analysis and research conducted during a field trip to the area of Pitomača vineyards, as well as on the in-depth interview with the president of the association of winegrowers and the aforementioned focus group. Preliminary data were used to define research questions and work objectives, as well as to define sample and design a questionnaire. Based on the preliminary research, the following research questions were defined:

- Are there preconditions for the inclusion of winegrowers in the tourist offer (the phase after the construction of the tourist interpretation centre; production and other capacities; long-term interests)

\footnotetext{
${ }^{1}$ Data obtained from a conversation with the president of the association of winegrowers and fruit growers "Aršanj" from Pitomača. There is no unique record in the area of the municipality since the local selfgovernment has taxed only holiday homes that are registered for the catering industry with the tax on holiday homes and there are still none of those in the vineyards by far.
} 
ToSEE - Tourism in Southern and Eastern Europe, Vol. 6, pp. 53-68, 2021.

R. Bakan, D. Tubić, B. Jaković: ASSOCIATING TO CREATE UNIQUE TOURIST EXPERIENCES ...

- What are the basic attractive elements for positioning the destination of a highly personalized experience in the wine tourism market

- Is there an interest of winegrowers and other stakeholders for a joint presence in the wine tourism market

- What are the main factors of the current "status quo" of the Pitomača vineyards in correlation with wine tourism.

According to research questions, the main goal of this paper is to explore the possibilities of creating an integrated tourist product based on traditional wine production, wine culture and gastronomy, heritage and customs on the example of a small wine-growing area in Municipality of Pitomača. For the purposes of the paper, the research was conducted by the survey method, using a structured questionnaire distributed by means of Google forms via e-mail. The survey questionnaire consisted of closed-ended questions, measured by a nominal (differential) scale and a Likert scale with five levels of intensity. New variables were used in the development of the questionnaire, derived from the previous primary research as explained in Chapter 3. The questions were divided into 5 groups, conceived in the form of a funnel, within which the research was conducted in the following order:

- socio-demographic characteristics of winegrowers

- qualitative and quantitative characteristics of production capacities of winegrowers

- attractive basis of the vineyard area for the needs of positioning in the wine tourism market

- interest association and the role of local government in engaging winegrowers in the wine tourism market

- limiting factors of business and involvement in tourism.

The survey included 30 winegrowers in the sampled area with a $50 \%$ rate of completed questionnaires (15 respondents). In the processing of the obtained data, a univariate statistical analysis was used, by means of which descriptive indicators, i.e. average values, were presented.

\subsection{Research results and discussion}

The survey included 15 vinegrowers from the area of Pitomača vineyards. All respondents were male - three of them aged 31 to 40, nine of them aged 41 to 50 and three of them aged 51 to 60 . In terms of educational structure, most respondents (eight of them) have a high school education, while four respondents completed graduate studies and three of them have only completed primary school. With regard to the annual quantity of produced wine, it ranges from 2000 to 3000 litres by four respondents, while the majority of the respondents (nine of them) is producing between 3001 and 6000 litres of wine and two respondents are producing more than 10000 litres of wine yearly. Thirteen respondents own holiday homes with a bathroom and a separate sleeping area within their properties and two respondents own holiday homes in form of a studio apartment. Only one of the respondents does not have a connection to the public electricity and water supply network. Moreover, eight respondents stated that they own several more properties which could be adapted for tourist reception. In addition to their 
ToSEE - Tourism in Southern and Eastern Europe, Vol. 6, pp. 53-68, 2021.

R. Bakan, D. Tubić, B. Jaković: ASSOCIATING TO CREATE UNIQUE TOURIST EXPERIENCES ...

vineyards and holiday homes, most respondents (nine of them) also own spacious outdoor areas (meadows and orchards) with gazebos, pergolas, and appliances for cooking in open fire. Ten respondents answered that they were familiar with the start of the construction of the tourist interpretation centre in the vineyards but did not know the details while five claimed that they knew the details and the purpose of the project.

Regarding the opinion on how much the completion of the project would contribute to the enrichment of the tourist offer of wine tourism in the Municipality of Pitomača, most of them said that they think it will be a place that will attract one-day visitors from a wider area but will not have greater effects on tourism consumption overall.

When asked to what extent they assess the need for association and joint participation of winegrowers in the wine tourism market, nine respondents said that the association of small winegrowers for joint participation in the market of wine and gastro tourism is important for market success, three respondents stressed that it is extremely significant for a serious appearance in the tourism market and that association is necessary and only three respondents stated that association is not crucial for someone to be competitive in the tourism market.

In regard to the familiarity of the respondents with the concept of a scattered hotel, most of the respondents, nine of them, were not familiar with the concept at all. After a brief explanation of the concept of the scattered hotel, the respondents were asked about the applicability of this model in the area of Pitomača vineyards. Their answers are shown in Graph 1. on the next page, which shows that the majority of respondents think that this area is ideal for the concept of scattered hotels due to the concentration of facilities that require relatively little investment to register as catering and tourism facilities.

It should be noted that most respondents stated that they would join the project of associating their venues into a scattered hotel if it were launched in the area of the Pitomača vineyards. In the survey, the respondents were asked to express their views on the elements on which Pitomača vineyards could build their recognition in the wine tourism market.

The best rated elements were: 1 "creation of original tourist products based on the local culture of life and work related to the tradition of wine production (celebration of wine saints, customs related to certain periods of the wine year, traditional dishes that accompany wine festivals, music, etc.)", which was rated with the highest level of agreement by ten respondents and 2 "existence of small wineries and tasting rooms" which was rated by all fifteen respondents with a high or very high level of agreement. Respondents' attitudes about all aspects of attractiveness are shown in Graph 2. 
ToSEE - Tourism in Southern and Eastern Europe, Vol. 6, pp. 53-68, 2021

R. Bakan, D. Tubić, B. Jaković: ASSOCIATING TO CREATE UNIQUE TOURIST EXPERIENCES ...

\section{Graph 1: Respondents' opinion on the applicability of the scattered hotel concept in the Pitomača vineyard area}

I think that there is no interest of tourists for this form of offer in vineyards

Due to the concentration of facilities that require relatively little investment to register as catering and tourism facilities, this area is ideal for this.

With additional education of the owners and explanation of the advantages of such a way of association, I think that the project could be..

The concept is interesting but I think it is difficult to implement

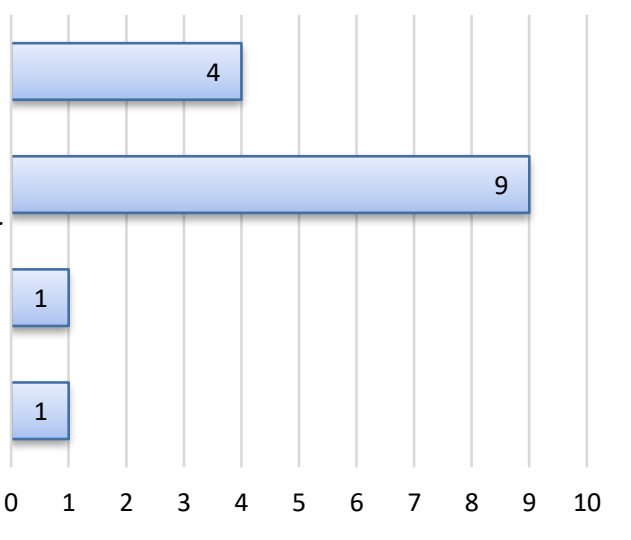

Source: author research

Graph 2: Sources of attractiveness for vineyards of Pitomača to build their recognition - respondent opinions
1. I don't agree at all
2.I don't agree
3. neither agree nor disagree
4. I agree
$\square 5$. I completely agree

creation of original tourist products based on the local culture of life and work related to the... connecting other forms of tourism with wine (gastrotourism, sports and recreational tourism,. additional offer within vineyards (accommodation, food services)

small wineries, wineries and tasting rooms

traditional non-industrial wine production the Hospitality of the hosts and the personalized approach to the guest

the peculiarities and diversity of the offer of "small series" wines

a large number of vacation houses and cellars with all the necessary infrastructure

a beautifull and unique landscape

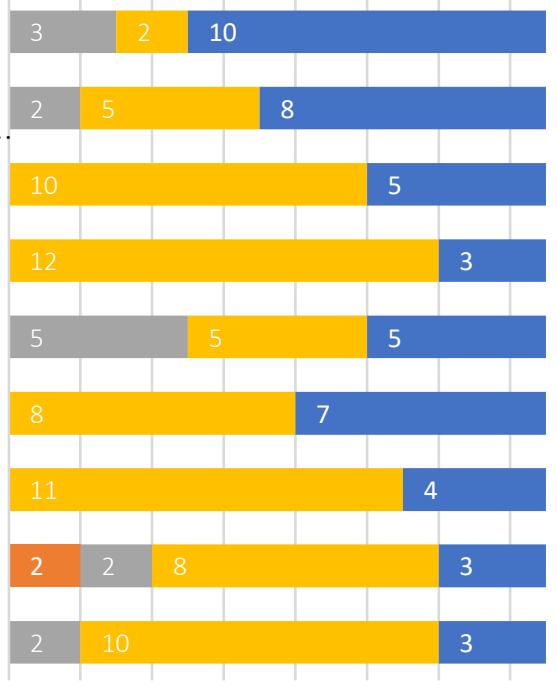

Source: author research 
ToSEE - Tourism in Southern and Eastern Europe, Vol. 6, pp. 53-68, 2021.

R. Bakan, D. Tubić, B. Jaković: ASSOCIATING TO CREATE UNIQUE TOURIST EXPERIENCES ...

The results of the empirical research (Graph 3) showed that the respondents, i.e. winegrowers mostly (average scores higher than 3.5) believe that the association of interests strongly encourages:

- more efficient marketing due to the joint appearance on the tourist market (average grade 3.9)

- easier placement of wine with additional tourist experiences - creating products of higher material and intangible value (average rating 3.8)

- higher degree of attractiveness due to overcoming the lack of accommodation capacities of small business units (average grade 3.8)

- transfer (exchange) of experience, information, knowledge and technology and more favourable procurement of goods and services of all stakeholders and thus certainly contribute to more efficient business and a higher degree of recognizability

- competitive advantage, which ultimately contributes to creating a recognizable and complete tourism product (average score 3.8).

\section{Graph 3: Respondents' attitudes regarding the impact of associating into microclusters and/or scattered hotels on certain business elements and increasing competitiveness}

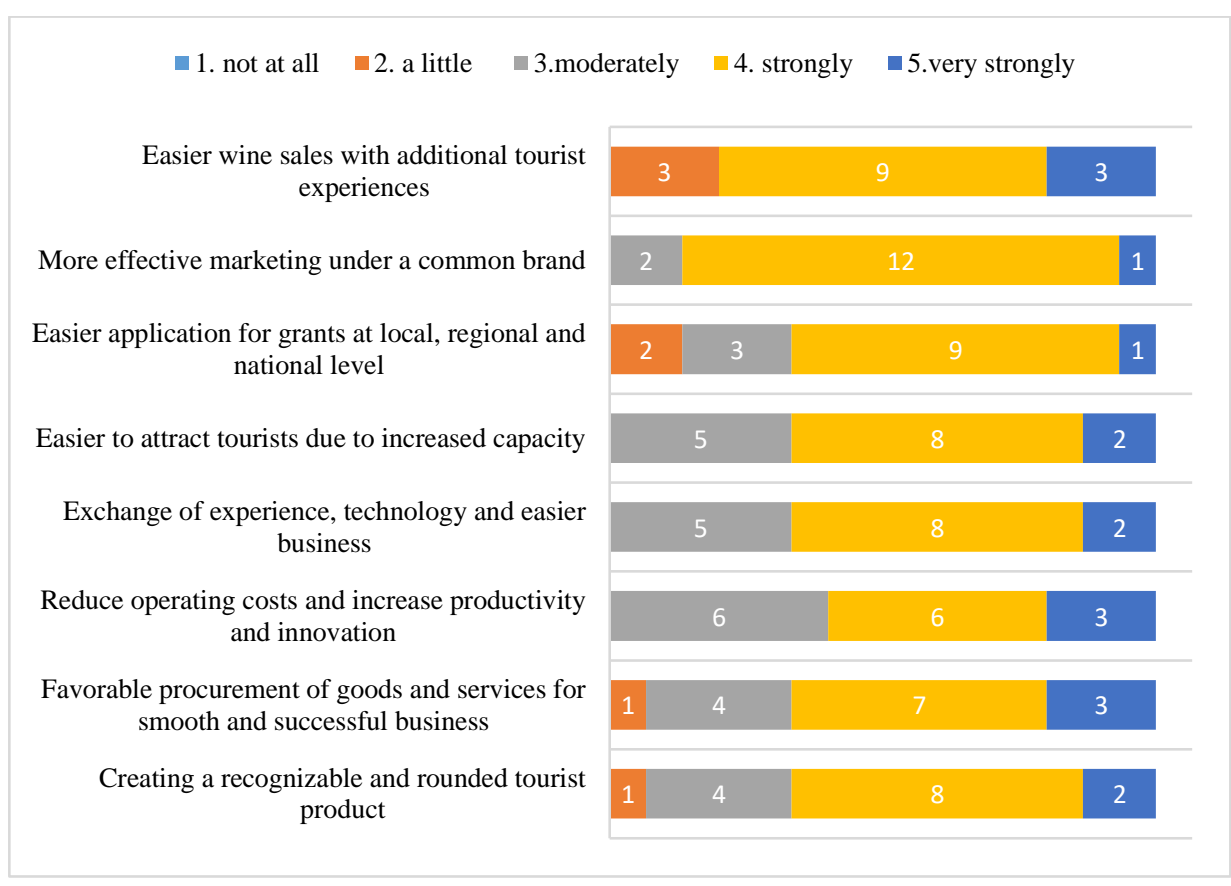

Source: author research

Opinions and attitudes of the respondents show that the vast majority of respondents recognize the attractiveness of the area and the opportunity provided by building a tourist interpretation centre in the vineyards and recognize the importance of associating and 
ToSEE - Tourism in Southern and Eastern Europe, Vol. 6, pp. 53-68, 2021.

R. Bakan, D. Tubić, B. Jaković: ASSOCIATING TO CREATE UNIQUE TOURIST EXPERIENCES ...

creating a common integrated tourism product of wine tourism enriched with additional experiential elements. However, it is clear that they are limited by a number of factors in launching entrepreneurial projects and ventures in the direction of additional tourist offer. The results of the empirical research indicate that the biggest limiting factors in undertaking entrepreneurial ventures and projects are the following:

- slow and inadequate administrative service (average score 1.9)

- lack of educational programs at the local and state level (average grade 2.3)

- lack of marketing activities at the local and state level (average score 2.3)

- non-incentive conditions for small business (average score 2.3)

- unfavourable loans and high interest rates (average grade 2.7)

- lack of information about incentive programs and poor flow of information (average score 2.7).

Graph 4: Opinions of the respondents regarding the role of the Municipality and/or tourist board in the initiative for the association of small winemakers into microclusters and/or scattered hotels

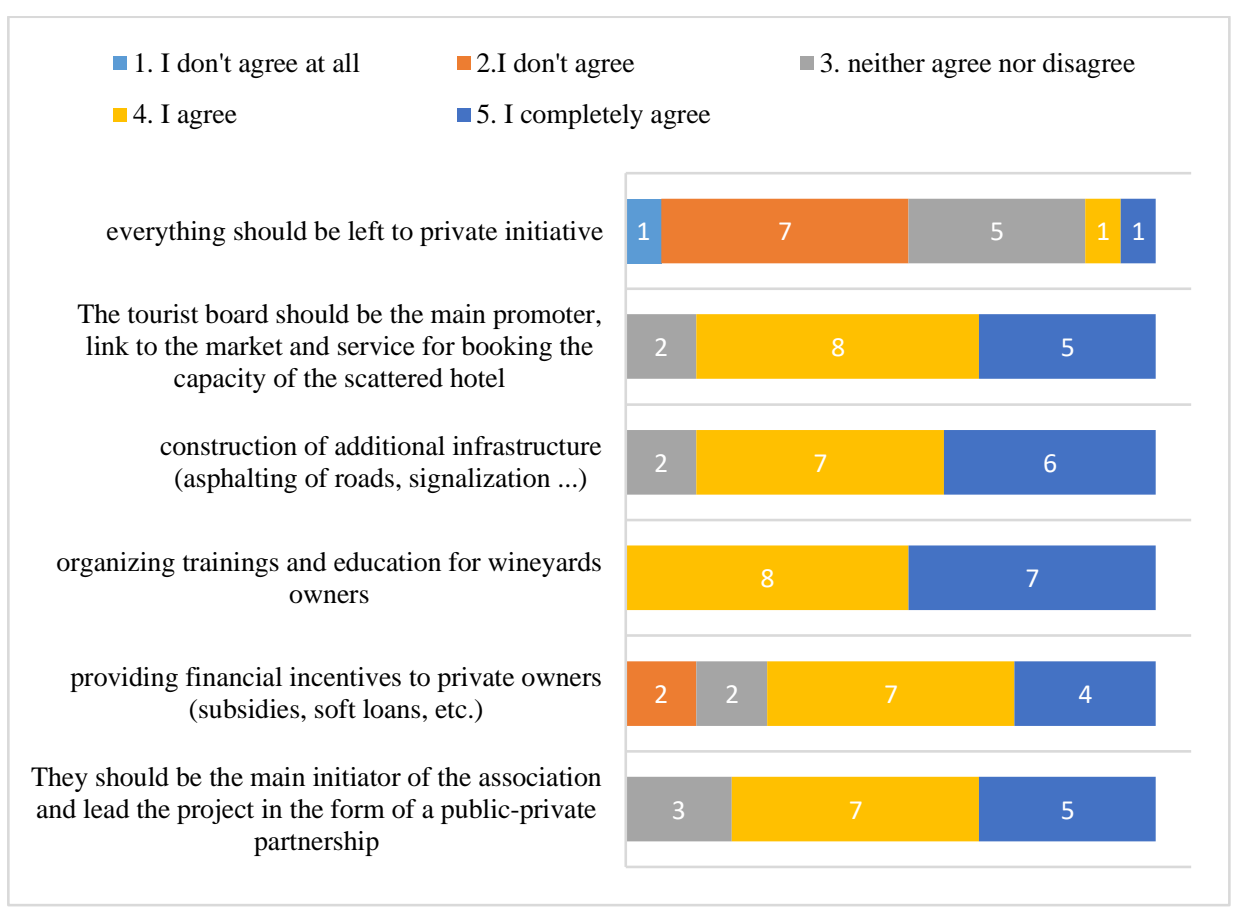

Source: author research

In their efforts to expand their activities with the tourist offer, all respondents confirm that they expect the help of the local self-government and/or Tourist board (see the Graph 4) such as: 
ToSEE - Tourism in Southern and Eastern Europe, Vol. 6, pp. 53-68, 2021.

R. Bakan, D. Tubić, B. Jaković: ASSOCIATING TO CREATE UNIQUE TOURIST EXPERIENCES ...

- organizing various types of formal and non-formal education that is primarily focused on marketing (work on social networks, independent advertising, etc.), the application process for various types of funds funded and co-financed by the European Union, state or regional and local government, as well as creating innovative and creative tourism products and services;

- construction or upgrading of the existing communal and tourist infrastructure

- various types of start-up funding, financing and co-financing

- marketing and communications with domestic and foreign tourism market.

In-field research of the wine-growing area, a conversation with the stakeholders in the construction project of the tourist interpretation centre and the owners of the vineyards indicate that the wine-growing area in Pitomača has the potential for the development of an interesting and original wine tourism product. The main resources for the potential development of wine tourism are: a large number of beautifully landscaped vineyards with holiday homes and cellars that require very little investment to be able to register as catering and tourism facilities located in a relatively small area (this fact is confirmed by the fact that fourteen respondents have holiday homes connected to all the necessary infrastructure, and a large number of them have additional facilities); long tradition of winemaking associated with a rich heritage related to the culture of production and consumption of wine and customs related to winemaking and other elements of intangible heritage as well as the great interest of owners of small wineries to be included in the tourist offer. As expected, numerous limitations that hinder the respondents in their desire to be involved in the tourism market have been noticed through the empirical research.

\section{CONCLUSION AND CONTRIBUTION}

Trends in the tourist demand market indicate the growing interest of tourists in oenology and gastronomy as the main attractive factor in choosing tourist destinations. The number of visits to rural, as yet undiscovered tourist destinations, building their market recognition on the pronounced characteristics of the offer based on elements of intangible cultural heritage, local culture of life and work and experiential elements that complement the basic offer of wine and gastro tourism is also growing. However, due to the fragmentation of the tourist offer of rural tourist destinations, in order for them to be competitive in the wine tourism market, there is a need for integrated planning and management of tourism development at the level of the entire destination and association of stakeholders, in this case owners of small wineries. The research showed that the main factors of success in the market were elements such as the need to supplement the basic offer of small wineries with additional experience elements, gastronomic and accommodation offer, promotion at a wider level and association for joint market presence. The observed attitudes concur with the results of some authors who have dealt with similar topics - such as Razović (2015) in his research on wine tourism as a special form of tourist offer in Dalmatia. Croatia is extremely rich in the diversity of wine production and the specifics of its vineyards, which is a great comparative advantage for the development of a recognizable wine and gastro tourism offer, but in many destinations, especially the continental ones, these comparative advantages have not yet been made into competitive ones. One of the reasons, as this paper points out, is the non- 
ToSEE - Tourism in Southern and Eastern Europe, Vol. 6, pp. 53-68, 2021.

R. Bakan, D. Tubić, B. Jaković: ASSOCIATING TO CREATE UNIQUE TOURIST EXPERIENCES ...

existent or still insufficiently developed approach to the integrated management of a tourist destination and the incoherence of the holder of the tourist offer. The concept of scattered hotels in rural areas is recognized as a successful model of association adorned with the originality of the offer based on the specifics of local culture of life and work (wine production, gastronomy, traditional crafts, art...) but as such it is still unknown to most potential wine tourism providers. This paper can help to raise the awareness of small winemakers, and even more so the awareness of the local community from which they expect help, for the need of joint work and association to create an original and interesting tourist offer of wine and gastro tourism and thus increase the number of tourist arrivals and create a source of income for local winemakers. Although there are vineyards with similar characteristics and similar problems in whole continental Croatia, the limitations of this research are that it was conducted on a relatively small number of respondents and only one small area was explored, so it is difficult to generalize the conclusions. Nevertheless, it can serve as a starting point for future research on a larger number of respondents in the observed area but also in neighbouring wine-growing areas in Virovitica-Podravina and Koprivnica-Križevci counties which would additionally examine their views on the possibilities and ways of associating into a certain microcluster of wine tourism. Moreover, upon the completion of the tourist interpretation centre in the vineyards, visitors should be examined from the very beginning in order to learn their impressions and the potential of the observed area as a destination of wine tourism, as well as their preferences and expectations in terms of oeno and gastro tourist experience.

\section{REFERENCES}

Aref, F., Gill, S. S. and Aref, A. (2010), "Assessing the level of community capacity building in tourism development in local communities", Journal of Sustainable Development, Vol. 3, No. 1, pp. 81-90.

Back, R.M., Lowry, L.L. and Higgins, L. M. (2021), „Exploring a wine farm micro-cluster: A novel business model of diversified ownership“, Journal of Vacation Marketing, Vol. 27, No. 1, pp. 103-116. https://doi.org/10.1177/1356766720954258

Binkhorst E. and Den Dekker, T. (2009), „Agenda for Co-Creation Tourism Experience Research“, Journal of Hospitality Marketing \& Management, Vol. 18, No. 2-3, pp. 311-327. https://doi.org/10.1080/19368620802594193

Björk, P. and Kauppinen-Räisänen, H. (2016), "Local food: a source for destination attraction”, International Journal of Contemporary Hospitality Management, Vol. 28, No. 1, pp. 177-194. https://doi.org/10.1108/IJCHM-05-2014-0214

Cucari, N., Wankowicz, E. and De Falco, S.E. (2019), "Rural tourism and Albergo Diffuso: A case study for sustainable land-use planning”, Land Use Policy, Vol. 82, pp. 105-119. https://doi.org/10.1016/j.landusepol.2018.11.050

Dragičević, M. (2012), Konkurentnost: projekt za Hrvatsku, Školska knjiga, Zagreb.

Fields, K. (2003), "Demand for the gastronomy tourism product: motivational factors", in Hjalager, A.M. and Richards, G. (Eds.), Tourism and gastronomy, Routledge, London, pp. 36-50.

Frost, W., Frost, J., Strickland, P. and Maguire, J.S. (2020), ,Seeking a competitive advantage in wine tourism: Heritage and storytelling at the cellar-door", International Journal of Hospitality Management, Vol. 87, 102460. https://doi.org/10.1016/j.ijhm.2020.102460

Getz, D. and Brown, G. (2006), „,Critical success factors for wine tourism regions: a demand analysis“, Tourism management, Vol. 27, No. 1, pp. 146-158. https://doi.org/10.1016/j.tourman.2004.08.002

Hall, C.M., Johnson, G., Cambourne, B., Macionis, N., Mitchell, R.D. and Sharples, E. (2000), , Wine tourism: An introduction“, in Hall, C.M., Sharples, E., Cambourne, B. and Macionis, N. (Eds.), Wine tourism around the world: Butterworth Heinemann, Oxford, pp. 1-23.

Hawley, K. (2017), „,Dining out is the main event“, in Ali R. (Ed.), Skift Megatrends 2017 - Defining the future of travel, Skift Magazine, viewed 31 January 2017, https://skift.com/2017/01/12/the-megatrendsdefining-travel-in-2017/ 
ToSEE - Tourism in Southern and Eastern Europe, Vol. 6, pp. 53-68, 2021.

R. Bakan, D. Tubić, B. Jaković: ASSOCIATING TO CREATE UNIQUE TOURIST EXPERIENCES ...

Hjalager, A.M. and Richards, G. (2002), Tourism and Gastronomy, Routledge, London, UK.

Herrera, C.F. (2012), „Gastronomy's importance in the development of tourism destinations“, in Jordan, P. (Ed.), World Tourism Organization, Global Report on Food Tourism, Vol. 4, UNWTO Publishing, Madrid, pp. 6-8.

Jang, S.S., Liu, Y. and Namkung, Y. (2011), „Effects of authentic atmospherics in ethnic restaurants: investigating Chinese restaurants“, International Journal of Contemporary Hospitality Management, Vol. 23, No. 5, pp. 662-680. https://doi.org/10.1108/09596111111143395

Jennings, G. and Nickerson, N. (Eds.). (2006), Quality tourism experiences, Routledge.

Le, T.H., Arcodia, C., Novais, M.A. and Kralj, A. (2019), „What we know and do not know about authenticity in dining experiences: A systematic literature review“, Tourism Management, Vol. 74, pp. 258275. https://doi.org/10.1016/j.tourman.2019.02.012

Lee, A.H., Wall, G. and Kovacs, J.F. (2015), „Creative food clusters and rural development through place branding: Culinary tourism initiatives in Stratford and Muskoka, Ontario, Canada", Journal of rural studies, Vol. 39, pp. 133-144. https://doi.org/10.1016/j.jrurstud.2015.05.001

Mehmetoglu, M. and Engen, M. (2011), „Pine and Gilmore's Concept ofExperience Economy and Its Dimensions: An Empirical Examination in Tourism“, Journal of Quality Assurance in Hospitality \& Tourism, Vol. 12, No. 4, pp. 237-255. https://doi.org/10.1080/1528008X.2011.541847

Michael, E.J. (2003), „Tourism Micro-Clusters“, Tourism Economics, Vol. 9, No. 2, pp. $133-145$. https://doi.org/10.5367/000000003101298312

Mirosa, M. and Lawson, R. (2012), „Revealing the lifestyles of local food consumers“, British Food Journal, Vol. 114, No. 6, pp. 816-825. https://doi.org/10.1108/00070701211234345

Morena, M., Truppi, T. and Del Gatto, M.L. (2017), "Sustainable tourism and development: the model of the Albergo Diffuso", Journal of Place Management and Development, Vol. 10, No. 5, pp. 447460. https://doi.org/10.1108/JPMD-08-2016-0057

Narodne novine [Official Gazette], No. 33/2014, viewed 2 May 2021, https://narod-nenovine.nn.hr/clanci/sluzbeni/2014_03_33_602.html

OECD (2012), Food and the Tourism Experience: The OECD-Korea Workshop, OECD Studies on Tourism, OECD Publishing, http://dx.doi.org/10.1787/9789264171923-en

Paniccia, P.M.A. and Leoni, L. (2019), „Co-evolution in tourism: The case of Albergo Diffuso“, Current Issues in Tourism, Vol. 22, No. 10, pp. 1216-1243, https://doi.org/10.1080/13683500.2017.1367763

Pine, B.J. II. and Gilmore, J.H. (1999), The Experience Economy: Work is Theater and Every Business is a Stage, Harvard Business School Press, Boston, MA.

Porter, M.E. (1998), "Clusters and the new economics of competition“, Harvard Business Review, Vol. 76, No. 6, pp. 77-90.

Porter, M.E. (1990), The Competitive Advantage of the Nations, The Free Press, New York.

Razović, M. (2015), Vinski turizam kao posebni oblik turističke ponude Dalmacije, Zbornik radova Veleučilišta u Šibeniku, No. 3-4, pp. 51-67.

Quadri-Felitti D. and Fiore A.M. (2012), „Experience economy constructs as a framework for understanding wine tourism“, Journal of Vacation Marketing, Vol. 18, No. 1, pp. 3-15. https://doi.org/10.1177/1356766711432222

Quadri-Felitti D. and Fiore A.M. (2013), „Destination loyalty: Effects of wine tourists’ experiences, memories, and satisfaction on intentions", Tourism and Hospitality Research, Vol. 13, No. 1, pp. 47-62. https://doi.org/10.1177/1467358413510017

Sundbo, J. and Sorensen, F. (Eds.). (2013). Handbook on the experience economy. Edward Elgar Publishing.

The Official website of Pitomača Municipality (2015), Development Strategy of the Municipality of Pitomača until 2020., viewed 15 April 2021, http://pitomaca.hr/wpcontent/uploads/2019/12/Strategija_razvoja_Opcine_Pitomaca_2015-2020.pdf

Tourist board of Pitomača (2015), Master Plan for Tourism Development in the Municipality of Pitomača until 2020, viewed 15 April 2021, https://tourism-pitomaca.hr/wp-content/uploads/2021/03/Glavniplan-razvoja-turizma-na-podruc\%CC\%8Cju-opc\%CC\%81ine-Pitomac\%CC\%8Ca-do-2020.godine.pdf

Tourist board of Pitomača (2017), Annual report, viewed 15 April 2021, https://tourism-pitomaca.hr/wpcontent/uploads/2021/03/Izvjes\%CC\%8Cc\%CC\%81e-o-radu-za-2017.-godinu.pdf

Tourist board of Pitomača (2019), Annual report, viewed 15 April 2021, http://pitomaca.hr/wpcontent/uploads/2019/03/15_16.pdf

Tourist board of Pitomača (2020), Annual report, viewed 15 April 2021, http://pitomaca.hr/wpcontent/uploads/2021/03/10.-Razmatranje-Izvje\%C5\%A1\%C4\%87a-o-radu-Turisti\%C4\%8Dkezajednice-i-Turisti\%C4\%8Dkog-ureda-Op\%C4\%87ine-Pitoma\%C4\%8Da-za-2020.-godinu.pdf 
ToSEE - Tourism in Southern and Eastern Europe, Vol. 6, pp. 53-68, 2021.

R. Bakan, D. Tubić, B. Jaković: ASSOCIATING TO CREATE UNIQUE TOURIST EXPERIENCES ..

Wu, D.C., Song, H. and Shen, S. (2017), "New developments in tourism and hotel demand modeling and forecasting", International Journal of Contemporary Hospitality Management, Vol. 29, No. 1, pp. 507-529. https://doi.org/10.1108/IJCHM-05-2015-0249

Villanueva, E. C. and Moscovici D. (2016), Sustainable wine tourism development in burgeoning regions: Lessons from New Jersey and Connecticut, International Journal of Economics and Business Research, Vol. 12, No. 4, pp. 313-332.

Rikard Bakan, MB Econ., senior lecturer

University of Applied Sciences in Virovitica

Department for tourism

M.Gupca 78, Virovitica, Croatia

$+38533492274$

rikard.bakan@vuv.hr

Dejan Tubić, $\mathrm{PhD}$, assistant professor

University of Applied Sciences in Virovitica

Department for tourism

M.Gupca 78, Virovitica, Croatia

+38533492261

dejan.tubic@vuv.hr

Božidar Jaković, MB Econ., senior lecturer

University of Applied Sciences in Virovitica

Department for tourism

M.Gupca 78, Virovitica, Croatia

+38533492263 